\title{
Experimental legal regimes for digital innovation and a special regulation mechanism: new concepts of russian legislation and first projects
}

\author{
Oksana Mamina*, and Ekaterina Kobzeva \\ Russian University of Transport, Moscow, Russia
}

\begin{abstract}
The paper examines the new concepts of Russian legislation introduced into the mechanism of legal regulation with the entry into force of the Federal Law "On Experimental Legal Regimes in the field of Digital Innovations in the Russian Federation" and analyzes the first projects approved as part of its implementation. Thus, one of the actively implemented types of regulatory technologies, as shown in the article, is the "regulatory sandboxes". The establishment of an experimental legal regime within the framework of the functioning of "regulatory sandboxes" means the application to legal entities and individual entrepreneurs of a special, different from the generally established legal regulation (special regulation and general regulation - in the definitions of the law under study). The article analyzes the prerequisites and possible results of the implementation of a flexible system of legal regulation aimed at stimulating the development of technologies and preventing possible negative consequences associated, inter alia, with the use of artificial intelligence. When writing the work, of general scientific methods were used (such as: dialectical, systematic, analysis, synthesis, induction, deduction, modeling, observation) and special private scientific methods of cognition (in particular, formal legal). In the course of using this methodology, the authors described in detail the distinctive characteristics and predictively outlined the features of a flexible system of legal regulation aimed at stimulating the development of technologies, as well as drew conclusions about the possibilities arising from the use of the mechanism of "regulatory sandboxes" in modern Russia.
\end{abstract}

\section{Introduction}

In January 2021, the Federal Law of July 31, 2020, No. 258-FZ "On Experimental Legal Regimes in the Sphere of Digital Innovations in the Russian Federation" (hereinafter - FZ No. 258) came into force in Russia. Pursuant to its provisions, persons involved in the development and implementation of digital innovations are given the opportunity to implement their practical application in the context of removing the restrictions established by regulatory legal acts ("sandboxes"). Thus, these modes will allow the business to reduce the time and costs for the development, testing, and implementation of new technologies, as well as reduce legal risks. Pursuant to Resolution of the Government of the Russian

\footnotetext{
* Corresponding author: maminaoi.miit@mail.ru
} 
Federation No. 1618 dated October 7, 2020, "On Amending Clause 1 of the Regulation on the Ministry of Economic Development of the Russian Federation", the Ministry of Economic Development of Russia is determined as an authorized federal executive body ensuring the normative legal regulation and the executing the powers provided for by Federal Law No. 258 on issues of experimental legal regimes in the field of digital innovations, with the exception of the direction of development, testing and implementation of digital innovations provided for in Paragraph 4 of Part 2 of Article 1 of the specified Federal Law. This law was adopted within the framework of the federal project "Normative regulation of the digital environment" aimed at implementing the tasks of the national program "Digital Economy of the Russian Federation", which in turn was formulated by the Decree of the President of the Russian Federation dated May 7, 2018, No. 204 "On national goals and strategic objectives of the development of the Russian Federation for the period up to 2024". This federal project provides for the development and adoption of a number of regulatory legal acts aimed at removing priority barriers that impede the development of the digital economy, in particular, in such areas as: civil circulation [12], financial technologies [15, 19], intellectual property, telecommunications, legal proceedings and notaries, standardization, etc.

The need to create a flexible system of legal regulation aimed both at stimulating the development of technologies and at preventing possible negative consequences associated with the use of artificial intelligence, robots and robotics objects is predetermined by the rapid development of the technologies themselves. The creation of such a flexible system, stimulation of the development of artificial intelligence technologies, including robots and robotics, is facilitated by regulatory or regulatory sandboxes. $[8,18]$ The sandbox metaphor is illustrative, as a particular experiment should be limited to participants, technology, applicable requirements, etc. Herewith, the metaphorical nature of legal terminology has already become characteristic of strategic documents related to the field of digital technologies. [3]

\section{Material and methods}

The basic premise for the institution of special regulation at sandbox bases is that technology development is often faster than general regulation implies. In these conditions, the state is in constant search of ways to make it more flexible, contributing to sustainable and efficient development in various areas of the economy. As Klaus Schwab, the founder and permanent president of the World Economic Forum, rightly notes, we need a new regulatory and legal climate, without which it is impossible to confidently apply innovative technologies. Outdated legislation is poorly adapted to the problems described - this is a huge handicap. [13] In such circumstances, and due to the fact that it is impossible to establish adequate regulation for most innovations without practical experience, states are looking for ways to test new approaches without fundamental changes in legislation [1]

In general, the regulatory sandbox mechanism provides methods for testing new technologies and business processes within a limited number of participants, accompanied by specific legal requirements, which means either the removal of certain mandatory requirements for experimental purposes, or the development of special requirements and "tailor-made" provisions. Both of these options have a limited time frame to validate new technology or business processes and the results of their implementation.

Herewith, analysts of the used approach of legal regulation, speaking about its prospects, draw attention to the fact that, on the one hand, since within the framework of the pandemic, digital technologies are gaining more and more importance in new spheres of public life, economy, state and municipal administration, the current situation with COVID-19 can lead to the development of both digital innovations and sandboxes $\backslash[4,14]$; on the other hand, 
however, there are doubts about the efficiency of flexible rules in balancing public interests and business strategies. [17]

\section{Results}

The objectives of the experimental legal regime are the formation, based on the results of its implementation, of new types, forms and methods of economic activity; development of competition; expanding the composition, improving the quality or availability of goods, works and services; increasing the efficiency of state or municipal administration; ensuring the development of science and social sphere; enhancement of general regulation based on the results of the implementation of the experimental legal regime; attracting investment in the development of entrepreneurial activity in the field of digital innovations in the Russian Federation; creating favorable conditions for the development and implementation of digital innovations. [5]

The establishment of the type of legal regime under study means the application of a special, different from the generally established legal regulation (special regulation and general regulation - in the definitions of the analyzed law) to business entities - legal entities and individual entrepreneurs. As a special regulation, the law defines normative legal regulation, which differs from general regulation and is established pursuant to Federal Law No. 258 by the program of the experimental legal regime in relation to participants in the experimental legal regime for a certain period and, unless otherwise provided by the program of the experimental legal regime, in a certain territory. If general regulation is established by federal laws, then special regulation is established in the cases provided for by the relevant federal laws. Special regulation on the part of the initiator (regulator) should include the following main components: regulation of interaction between the regulator and the subjects; procedures for acquiring, suspending and terminating the status of a base entity; introduction of mandatory conditions for participation (e.g., obtaining licenses, permits, etc.); regulations for monitoring the activities of the base entity.

Thus, a similar regime is introduced to support and develop priority sectors of the economy, to accelerate the emergence and implementation of new products and services in the areas of application of digital innovations. The implementation of an experimental regime within the framework of the formation of a new "regulatory" environment allows for some relaxation in legal regulation over a certain period of time in the areas of development, testing and implementation of digital innovations in areas that are significant for society. [2] Analyzing the interdependence and mutual influence of the development of digital technologies and the formation of this environment in the context of the digitalization of the economy, social sphere and other components of the modern high-tech world, the researchers conclude that the formation of a fundamentally different regulatory landscape as a backbone legal basis in the regulation of artificial intelligence, remote identification and authentication of a person, big data, technologies of augmented and virtual reality. [6]

The analyzed Federal Law No. 258 makes it possible to free the use of innovations from legal norms that limit them in eight areas (the list of which is possible for addition), which, pursuant to researchers, is already a lot to start with. Thus, experimental legal regimes in the field of digital innovation can be established in such areas of development, testing and implementation of digital innovations as:

1) medical activities, including the use of telemedicine technologies and technologies for collecting and processing information about the health status and diagnoses of citizens, pharmaceutical activities;

2) design, production and operation of vehicles, including highly automated vehicles and unmanned aerial vehicles, certification of their operators, provision of transport and logistics services and organization of transport services; 
3) agriculture;

4) financial market;

5) the sale of goods, works, services by remote means;

6) architectural and construction design, construction, overhaul, reconstruction, demolition of capital construction, operation of buildings, structures;

7) the provision of state and municipal services and the implementation of state control (supervision) and municipal control;

8) industrial production (industry);

9) other areas of development, testing and implementation of digital innovations established by the Government of the Russian Federation.

The legal experiment is supposed to be extended to systems based on digital innovations, including big data [11], blockchain, neurotechnology and artificial intelligence, quantum technologies, robotics, etc. However, the project does not define any complete list of such technologies, but only uses the term "digital innovation" defined as a new or significantly enhanced product (product, work, service, protected result of intellectual activity) or a process, a new sales method or an organizational method in a business. practice, organization of jobs or in external relations. [10] In practice, regulatory or regulatory sandboxes are bases that are created by initiators (regulators or regional authorities) for the purpose of testing or limiting the use of innovations that provide for a specific regulatory regime for participants within a controlled environment.

The birthplace of "regulatory sandboxes" is the UK, where the first such platform was created in 2016. [7] Similar mechanisms also exist in the USA, Canada, China, Australia, Singapore, UAE, Hong Kong, Switzerland, Thailand, Indonesia, the Republic of Kazakhstan, Bahrain, Jordan, Sierra Leone, and a number of other countries. Undoubtedly, over the next few years, the list of countries will be expanded, since states with different legal systems and political traditions are interested in this institution. $[9,15]$ The platform of the experimental legal regime is also planned in Moscow (Ref.: Federal Law No. 123-FZ of April 24, 2020, "On conducting an experiment to establish special regulation in order to create the necessary conditions for the development and implementation of artificial intelligence technologies in the constituent entity of the Russian Federation - the city of federal significance Moscow and amending Articles 6 and 10 of the Federal of the Law "On Personal Data")

Being under state control, the sandbox can be transformed based on special rules. New financial products, high technologies, and innovative business models or processes can be validated pursuant to a specific set of rules, regulations, and requirements that ensure appropriate safeguards and protection of the public interest. Herewith, the territorial boundaries of the "sandbox" are not legally established - they will be able to work within a municipality, a region or the entire country. The law largely regulates the procedural mechanism for creating, changing, canceling, and monitoring sandboxes. Within the framework of this mechanism, at the request of the initiator or the request of the regulator, the authorities and the business community will be able to evaluate the initiative and proposals for special regulations and decide on the possibility of its settlement.

Herewith, researchers pay attention to possible problematic issues of the practical implementation of this mechanism. [10] These include issues of corruption risks associated with the lack of statutory decision-making criteria, risks of unfair components and limited disclosure of business data when processing an application, tax burden for participants in sandboxes, and others.

\section{Conclusion}

Currently, the stage of independent anti-corruption expertise is undergoing a draft Federal Law "On Amendments to Certain Legislative Acts of the Russian Federation in Connection 
with the Adoption of the Federal Law" On Experimental Legal Regimes in the Sphere of Digital Innovations in the Russian Federation "(in terms of the development of artificial intelligence technologies and big data ) ", Which defines the list of individual legislative requirements that, by decision of the Government of the Russian Federation, pursuant to the program of the experimental legal regime, may not be applicable within the framework of experimental legal regimes.

As noted above, the draft law provides for exemptions from certain legislative requirements in such areas of development and testing of digital innovations as medical activity and telecommunications, design, production and operation of highly automated vehicles, including unmanned aerial vehicles, provision of transport and logistics services and organization of transport services; the use of artificial intelligence systems in the provision of services. The proposed list of exemptions from certain legislative requirements suggests the possibility of non-application of the provisions of the relevant federal laws when establishing an experimental legal regime.

Thus, in mid-March 2021, it became known about the first seven projects submitted by the Government of the Russian Federation, for which a special experimental legal regime for digital innovations can be used. The project list comprises the projects offered by MTS PJSC and Yandex. The first project, presented by MTS, is interesting in that it provides the possibility of remotely concluding contracts for the provision of communication services using biometric technologies, i.e. it will provide a practical opportunity to conclude an agreement on cellular communication services without directly visiting the salon of the cellular operator, and identity identification will be carried out biometrically.

The second MTS PJSC project, selected by the Government, which will be subject to a special legal regime, is related to telemedicine. The initiative aims to enhance the availability of qualified health care services, including when health facilities offering relevant services are unavailable. For the successful implementation of this project, a sufficiently significant revision of the legislation concerning the fundamentals of protecting the health of citizens in the Russian Federation is required. At the moment, such changes should primarily affect Federal Law No. 323 "On the basics of protecting the health of citizens in the Russian Federation." In this regard, Article 36.2 of this Law, in particular, which imposes some restrictions on medical care and the provision of consultations to a patient using telemedicine technologies, is primarily subject to withdrawal within the framework of the application of experimental legal regimes. A number of changes should touch upon issues that determine in what order and by whom decisions on the use of innovative services are made, despite their absence in the list, standards of medical care and clinical guidelines as of the date of the experimental implementation of the innovative service. Pursuant to experts, the implementation of this initiative should significantly affect the change in legislation in this area.

Also in the list of the first "sandboxes" was an innovative project of the company "Yandex", the essence of which is the commercial use of unmanned ground transport - highly automated vehicles (HAVs). The current legislation on road safety does not allow the operation of cars without a driver, and the requirements of the experiment on trial operation of highly automated vehicles on public roads significantly limit the development of HAVs technologies. This innovation involves a significant revision of the legislation of the Russian Federation and the introduction of significant changes into it (in such matters as insurance, technical inspection, traffic safety). For this reason, the bill provides for the possibility of non-application of certain provisions of the Federal Law "On Road Safety", the Federal Law "On Compulsory Insurance of Civil Liability of Vehicle Owners", the Federal Law "Charter of Automobile Transport and Urban Land Electric Transport", the Federal Law "On the Technical Inspection of Vehicles and on Amendments to Certain Legislative Acts of the Russian Federation" etc. 
The electronic database of the Parliament has the draft law No. 1129501-7 "On Amendments to Certain Legislative Acts of the Russian Federation in Connection with the Adoption of the Federal Law "On Experimental Legal Regimes in the Sphere of Digital Innovations in the Russian Federation", which introduces a number of exceptions to the current legislation governing communications, the use of personal data, as well as involves the introduction of significant changes to the Air Code in matters relating to traffic safety and allows for legal exemptions for certain digital innovative projects. The list of projects to which it is planned to be provided with a special legal regime is listed in the explanatory note to the draft law (No. 1129501-7). And preliminary conclusions about the efficiency and adequacy of the use of the mechanism of "regulatory sandboxes" can be made only after summing up the results of the implementation of the first projects.

\section{References}

1. T.A. Andronova, O.A. Tarasenko, Bankovskoye pravo 3, 31 (2018)

2. S.T. Artemova, N.A. Zhil'tsov, O.I. Cherdakov, Konstitutsionnoye i munitsipal'noye pravo 10, 41 (2020)

3. M.L. Davydova, Vestnik Volgogradskogo gosudarstvennogo universiteta. Seriya 2: YAzykoznaniye 19(4), 52 (2020)

4. A.A. Yefremov, V.N. Yuzhakov, Monitoring ekonomicheskoř situatsii v Rossii: tendentsii i vyzovy sotsial'no-ekonomicheskogo razvitiya 13(115), 31 (2020)

5. Ye.A. Kuklina, Upravlencheskoye konsul'tirovaniye 7(127), 39 (2019)

6. T.A. Polyakova, A.A. Chebotareva, Informatsionnoye pravo 2, 4 (2020)

7. I.A. Podkolzina, Mirovaya ekonomika i mezhdunarodnyye otnosheniya 65(2), 45 (2021)

8. G.F. Ruchkina, Bankovskoye pravo 5, 7 (2020)

9. G.F. Ruchkina, V.K. Shaydullina, Bankovskoye pravo 2, 7 (2018)

10. D.R. Salikhov, Tsifrovoye pravo 1(2), 17 (2020)

11. E.V. Talapina, Vestnik Sankt-Peterburgskogo universiteta. Pravo 11, 4 (2020)

12. Ye.V. Ushakova, Ye.I. Kobzeva, Teoriya prava i mezhgosudarstvennykh otnosheniy 2(12), 40 (2020)

13. K. Schwab, Technologies of the fourth industrial revolution. Top Business Awards, 320 (2018)

14. D. Ahlstrom, J.-L. Arregle, M.A. Hitt, G. Qian, X. Ma, D. Faems, J. of Management Studies 57(3), 411 (2020)

15. A.V. Ostroushko, L.A. Bukalerova, R.V. Shagieva, Lecture Notes in Networks and Systems 111, 627 (2020)

16. V. Sangwan, N. Harshita, P. Prakash, S. Singh, Studies in Economics and Finance 37(1), 71 (2019)

17. D. Zetzsche, R. Buckley, D. Arner, J. Barberis, European banking institute working paper series 23(1), 31 (2017). doi.org/10.2139/ssrn.3018534

18. A. Yefremov, Communications in Computer and Information Science 1038, 82 (2019)

19. W. Yuspin, Y.R.A. Putri, M. Ikbal, International J. of Innovation, Creativity and Change 12(2), 338 (2020) 